\title{
Acute gastroenteritis and enteric viruses in hospitalised children in southern Brazil: aetiology, seasonality and clinical outcomes
}

\author{
Sonia Maria Raboni ${ }^{1,2} /^{+}$, Guilherme Augusto Costa Damasio ${ }^{3}$, Carla EO Ferreira ${ }^{3}$, Luciane A Pereira ${ }^{1}$, \\ Meri B Nogueira', Luine R Vidal', Cristina R Cruz ${ }^{4}$, Sergio M Almeida ${ }^{1,5}$ \\ 'Laboratório de Virologia, Hospital de Clínicas ²Departamento de Doenças Infecciosas ${ }^{3}$ Programa de Pós-Graduação em Microbiologia, \\ Parasitologia e Patologia ${ }^{4}$ Departamento de Pediatria, Universidade Federal do Paraná, Curitiba, PR, Brasil \\ ${ }^{5}$ Faculdades e Instituto de Pesquisa Pelé Pequeno Príncipe, Complexo Pequeno Príncipe, Curitiba, PR, Brasil
}

Viral acute gastroenteritis $(A G)$ is a significant cause of hospitalisation in children younger than five years. Group A rotavirus (RVA) is responsible for $30 \%$ of these cases. Following the introduction of RVA immunisation in Brazil in 2006, a decreased circulation of this virus has been observed. However, AG remains an important cause of hospitalisation of paediatric patients and only limited data are available regarding the role of other enteric viruses in these cases. We conducted a prospective study of paediatric patients hospitalised for AG. Stool samples were collected to investigate human adenovirus (HAdV), RVA, norovirus (NoV) and astrovirus (AstV). NoV typing was performed by nucleotide sequencing and phylogenetic analysis. From the 225 samples tested, 60 (26\%) were positive for at least one viral agent. HAdV, NoV, RVA and AstV were detected in 16\%,8\%,6\% and $0 \%$ of the samples, respectively. Mixed infections were found in nine patients: HAdV/RVA (5), HAdV/NoV (3) and HAdV/NoV/RVA (1). The frequency of fever and lymphocytosis was significantly higher in virus-infected patients. Phylogenetic analysis of NoV indicated that all of these viruses belonged to genotype GII.4. The significant frequency of these pathogens in patients with AG highlights the need to routinely implement laboratory investigations.

Key words: gastroenteritis - children - rotavirus - norovirus - astrovirus - human adenovirus

Acute gastroenteritis (AG) is the most common gastrointestinal inflammatory condition affecting people in both developed and developing countries (Andreasi et al. 2008, Domínguez et al. 2009). Worldwide, diarrhoea remains the second leading cause of death in children younger than five years. Around 1.5 million of children die annually as a result of AG, which represents $15 \%$ of all deaths that occur in this population group (BoschiPinto et al. 2008, Black et al. 2010, Wardlaw et al. 2010 ). In the United States of America (USA), 200,000 children are hospitalised each year with this disease, resulting in 300-400 deaths, and thereby generating a high economic impact (McCollough \& Sharieff 2006). In Brazil, AG represents a major cause of morbidity and mortality in the first year of life and, in 2006, about 120,000 hospitalisations of children less than five years occurred due to AG (RIPSA 2008).

Over 20 different types of viruses have been identified as etiologic agents of AG, but the major viruses associated with acute diarrhoea in children can be divided into four different families: Reoviridae [rotavirus (RV)], Caliciviridae [norovirus (NoV) and sapovirus], Astroviridae [astrovirus (AstVs)] and Adenoviridae [ad-

doi: 10.1590/0074-0276140066

+ Corresponding author: sraboni@ufpr.br

Received 23 February 2014

Accepted 22 May 2014 enovirus (AdV)] (Santos et al. 2007). Other viruses, such as aichivirus, human parechovirus and human bocavirus have been described in faecal samples from patients with diarrhoea, but their association with AG has still not been established (Chhabra et al. 2013).

Since the mid-2000s, two RV vaccines became available, a monovalent RV vaccine (Rotarix ${ }^{\circledR}$, GlaxoSmithKline Biologicals Inc) and a pentavalent RV vaccine (RV5, RotaTeq ${ }^{\circledR}$, Merck \& Co, Inc). Both vaccines are recommended by the World Health Organization, have been used in several countries and studies have demonstrated a significant reduction of hospitalisation and mortality due to RV gastroenteritis (Justino et al. 2012, Lopman et al. 2012, Soares-Weiser et al. 2012). Brazil was one of the first countries to introduce universal vaccination against RVA, Rotarix ${ }^{\circledR}$, which has been provided free through the public health system since March of 2006. Before the introduction of the group A RV (RVA) vaccine in Brazil, the frequency for this virus in the population with $A G$ in our institution was $30 \%$. The number of RVA positive cases has decreased substantially since then (Pereira et al. 2011), while other pathogens are now reported more frequently.

NoVs have been recognised as the major causes of non-bacterial AG in all age groups in industrialised countries and are frequently associated with food and water-borne outbreaks. Human NoV cannot be grown in cell culture, they are non-enveloped RNA viruses with icosahedral symmetry and are divided into five genogroup (GI-GV), which are further divided into $>30$ genotypes, with genogroups GI and GII being associated with human infections (Mead et al. 1999, Hardy 2005, Patel et al. 2009, Khamrin et al. 2010, Kroneman et al. 2013). 
Human AdV (HAdV) is a non-enveloped DNA virus with icosahedral symmetry. The AdV has been associated with a wide spectrum of clinical manifestations, including respiratory, gastrointestinal, ocular, neurological and urinary tract infections. This family comprises 55 different serotypes (HAdV 1-55) grouped into seven subgenera (A-G), of which the genotypes 40, 41 and more rarely, 38 are related to acute diarrhoea (Wold \& Horwitz 2007, Ramani \& Kang 2009, Walsh et al. 2010).

Human AstVs (HAstVs) are non-enveloped RNA viruses with icosahedral symmetry. They are classified in eight serotypes (HAstVs 1-8), which are further divided into four subtypes (1a, 1b, 1c and 1d). Studies have shown that colonisation or infection by HAstV may be associated with necrotising enterocolitis, especially in preterm infants (Santos \& Cardoso 2005, Marshall et al. 2007, Bagci et al. 2010).

To assess the impact of these enteric viruses in the aetiology of AG in hospitalised children in our institution, this study aimed to identify (i) the frequency of RVA, HAdV, HAstV and NoV in stool samples, (ii) report the clinical findings of these infections, (iii) analyse the displacement of these viruses after the decrease in RVA cases during the period between September 2010-September 2011 and (iv) and genotypically characterise the NoV detected.

\section{SUBJECTS, MATERIALS AND METHODS}

Material - This study evaluated 225 stool samples from hospitalised paediatric patients, which were sent to the Virology Laboratory of the Faculty of Medicine Clinics Hospital, Federal University of Paraná (HCUFPR) to test for RVA between the period of September 2010-September 2011. Medical records of the patients were reviewed to evaluate clinical, laboratory and demographic data. The HC-UFPR Institutional Review Board approved the study (IRB\#0221.0.208.000-10).
The HC-UFPR is a tertiary academic care hospital where patients with severe infections are referred and AG is one of the most frequent causes of paediatric hospital admissions.

$R V$ detection - RVA antigen detection was carried out using the enzymatic immunoassay Rotascreen $\mathrm{II}^{\circledR}$ kit (Microgen Bioproducts, UK), according to the manufacturer's instructions.

Viral DNA/RNA extraction - DNA/RNA was extracted from $150 \mu \mathrm{L}$ of clarified $10 \%$ faecal suspension with the buffer Tris- $\mathrm{HCl}(0.01 \mathrm{M})-\mathrm{CaCl}_{2}(0.0015 \mathrm{M})$ by using a commercial kit (Intron Biotechnology Inc, South Korea) according to the manufacturer's instructions. Pseudotrabies viruses (PRV) were added to the lysis buffer at a concentration of $1.74 \times 10^{-8} \mathrm{ng} / \mu \mathrm{L}$ for use as an internal control for extraction.

$A d V$ detection - Generic primers and amplification tests were carried out as described by Avellón et al. (2001) (Table I) with some modifications. Briefly, $2.5 \mu \mathrm{L}$ of extraction product was added to $22.5 \mu \mathrm{L}$ of a PCR mix (Bioron, Ludwigshafe, GE) containing $2.5 \mathrm{mM}$ dNTPs, $1.25 \mathrm{U}$ of Taq DNA Polymerase, $160 \mathrm{mM}\left(\mathrm{NH}_{4}\right)_{2} \mathrm{SO}_{4}$, $670 \mathrm{mM}$ Tris- $\mathrm{HCl}$ ( $\mathrm{pH} \mathrm{8.8),} 25 \mathrm{mM} \mathrm{MgCl}$ and primary amplification primers for AdV and PRV at a concentration of $10 \mathrm{pmol} / \mu \mathrm{L}$. Amplification was carried out on a Mastercycler Personal (Eppendorf Inc, Hamburg, GE) thermocycler with the following cycling conditions: one hold of $94^{\circ} \mathrm{C} / 2 \mathrm{~min}, 40$ cycles of $94^{\circ} \mathrm{C} / 60 \mathrm{~s}, 50^{\circ} \mathrm{C} / 60 \mathrm{~s}$, $72^{\circ} \mathrm{C} / 60 \mathrm{~s}$ and one extension step of $72^{\circ} \mathrm{C} / 6 \mathrm{~min}$. For the second reaction, $1 \mu \mathrm{L}$ of primary amplification product was added to $24 \mu \mathrm{L}$ of a new PCR mix similar to that for the primary amplification, but containing secondary amplification primers. PCR products were resolved on $1 \%$ agarose gel electrophoresis stained with ethidium bromide $(0.5 \mu \mathrm{g} / \mathrm{mL})$.

TABLE I

Sequences of the primers used in polymerase chain reaction (PCR) and reverse transcription-PCR for the detection of adenovirus (AdV), pseudorabies viruses (PRV), norovirus (NoV) and astrovirus (AstV)

\begin{tabular}{|c|c|c|c|c|c|}
\hline Primer & Sequence 5'-3' & Gene target & Nested-PCR & Product & Reference \\
\hline ADHEX $2 \mathrm{~F}$ & СССМТТYААСCACCACCG & AdV & Yes & $169 \mathrm{bp}$ & Avellón et al. (2001) \\
\hline ADHEX 1R & ACATCCTTB CKGAAGTTCCA & Hexon & & & \\
\hline ADHEX 2R & KATGGGGTARAGCATGTT & & & & \\
\hline ADHEX $1 F$ & AACACCTAYGASTACATGAAC & & & & \\
\hline PRV 1+ & CGCGTGGTCTACGGGGACACGGA & PRV DNA & Yes & $140 \mathrm{bp}$ & Pozo and Tenorio (1999) \\
\hline PRV 1- & ATGACGCCGATGTACTTCTTCTT & polymerase & & & \\
\hline PRV 2+ & GGGACACGGACTCGGTCTCC & & & & \\
\hline PRV 2- & CCGGAAGGTCTTCTCGCACTC & & & & \\
\hline JV12 & ATACCACTATGATGCAGATTA & NoV RNA & No & $430 \mathrm{bp}$ & Vinjé and Koopmans (1996) \\
\hline JV13 & TCATCATCACCATAGAAAGAG & polymerase & & & \\
\hline Mon 270F & CAACTCAGGAAACAGGGTGT & AstV & No & 449 bp & Noel et al. (1995) \\
\hline Mon 269R & TCAGATGCATTGTCATTGGT & ORF2 & & & \\
\hline
\end{tabular}

ORF: open reading frame. 
AstV and NoV detection - Reverse transcriptionpolymerase chain reaction (RT-PCR) was performed for detection of HAstV and NoV. First-strand cDNA was synthesised using random primers and a RT system (SuperScript III ${ }^{\circledR}$ Reverse Transcriptase, Invitrogen, USA). Briefly, cDNA was obtained by adding $1 \mu \mathrm{L}$ random primer $\left(3 \mu \mathrm{g} / \mu \mathrm{L}\right.$, Invitrogen $\left.{ }^{\mathrm{TM}}\right)$ and $1 \mu \mathrm{L}$ of ultrapure water in $7.5 \mathrm{~mL}$ of RNA, followed by incubation for 5 min at $65^{\circ} \mathrm{C}$. Then, it was added $10.5 \mu \mathrm{L}$ of a RT-master mix containing $4 \mu \mathrm{L}$ of deoxynucleotide triphosphates (dNTPs) (2.5 mM each), $4 \mu \mathrm{L}$ of cDNA buffer $(5 \mathrm{x}), 2 \mu \mathrm{L}$ of $0.1 \mathrm{M}$ dithiotreitol (DTT) (Invitrogen ${ }^{\mathrm{TM}}$ ) $0.25 \mu \mathrm{L}$ of RNase inhibitor RNase OUTTM $\left(40 \mathrm{U} / \mu \mathrm{L}\right.$, Invitrogen $\left.{ }^{\mathrm{TM}}\right)$ and $0.25 \mu \mathrm{L}$ of enzyme reverse transcriptase SuperScript $^{\circledR}$ III $\left(2.000 \mathrm{U} / \mu \mathrm{L}\right.$, Invitrogen $\left.{ }^{\mathrm{TM}}\right)$, with subsequent incubation for $5 \mathrm{~min}$ at $25^{\circ} \mathrm{C}, 60 \mathrm{~min}$ at $50^{\circ} \mathrm{C}$ and 15 $\min$ at $70^{\circ} \mathrm{C}$. Generic primers and amplification tests for $\mathrm{HAstV}$ and NoV were carried out as reported by Noel et al. (1995) and Vinjé and Koopmans (1996), respectively (Table I). Briefly, $2.5 \mu \mathrm{L}$ of extraction product were added to $22.5 \mu \mathrm{L}$ of a PCR mix (Bioron, GE) containing 2.5 $\mathrm{mM}$ dNTPs, $1.25 \mathrm{U}$ of Taq DNA polymerase, $160 \mathrm{mM}$ $\left(\mathrm{NH}_{4}\right)_{2} \mathrm{SO}_{4}, 670 \mathrm{mM}$ Tris- $\mathrm{HCl}(\mathrm{pH} 8.8), 25 \mathrm{mM} \mathrm{MgCl}$ and primary amplification primer for $\mathrm{NoV}$ or $\mathrm{HAstV}$ at a concentration of $10 \mathrm{pmol} / \mu \mathrm{L}$. NoV amplification was carried out on a Mastercycler Personal (Eppendorf Inc) thermocycler programmed with the cycling conditions: $94^{\circ} \mathrm{C}$ for $2 \mathrm{~min}$ followed by 30 cycles of $94^{\circ} \mathrm{C} / 60$ $\mathrm{s}, 37^{\circ} \mathrm{C} / 30 \mathrm{~s}, 72^{\circ} \mathrm{C} / 30 \mathrm{~s}$ and an elongation step of $72^{\circ} \mathrm{C} / 6$ min. HAstV amplification was performed using the same cycling protocol described for HAdV. Both PCR products were resolved on $1 \%$ agarose gel electrophoresis stained with ethidium bromide $(0.5 \mu \mathrm{g} / \mathrm{mL})$. The gels were photographed under ultraviolet light and the bands were analysed using the E-Capt program.

Nucleotide sequencing - Nucleotide sequencing of positive samples was performed to genotype the NoV detected. The initial amplification was performed using three sets of primers described by Vinjé et al. (2004) (Table II), with one being GI specific, one being GII spe- cific and the third exhibiting no genogroup specificity. Briefly, $2.5 \mu \mathrm{L}$ of cDNA was added to $22.5 \mu \mathrm{L}$ of a PCR mix (Bioron) containing $2.5 \mathrm{mM}$ dNTPs, $1.25 \mathrm{U}$ Taq DNA polymerase, $160 \mathrm{mM}\left(\mathrm{NH}_{4}\right)_{2} \mathrm{SO}_{4}, 670 \mathrm{mM}$ Tris$\mathrm{HCl}(\mathrm{pH} 8.8), 25 \mathrm{mM} \mathrm{MgCl}_{2}$ and primary genotyping primers for $\mathrm{NoV}$ at a concentration of $10 \mathrm{pmol} / \mu \mathrm{L}$. The amplification was carried out on a Mastercycler Personal (Eppendorf Inc) thermocycler programmed with the cycling conditions: $94^{\circ} \mathrm{C}$ for $1 \mathrm{~min}$, followed by 40 cycles of $94^{\circ} \mathrm{C} / 60 \mathrm{~s}, 44^{\circ} \mathrm{C} / 60 \mathrm{~s}, 72^{\circ} \mathrm{C} / 60 \mathrm{~s}$ and an elongation step of $72^{\circ} \mathrm{C} / 10 \mathrm{~min}$. Afterwards, the PCR products were resolved on $1.5 \%$ agarose gel electrophoresis stained with ethidium bromide $(0.5 \mu \mathrm{g} / \mathrm{mL})$.

The amplicons obtained from one of the three sets of primers were subjected to sequencing reactions with the same primers. PCR products were purified using the Invisorb ${ }^{\circledR}$ Fragment Clean up (Invitek GmbH, Berlin, GE) kit, according to the manufacturer's instructions. Sequencing reactions were carried out using a Big Dye $^{\circledR}$ Terminator v.3.1 kit and the ABI3130 automated sequencer (Applied Biosystems, CA, USA).

Multiple sequence alignments were carried out using CLUSTALW software from BioEdit v.7.0.9 package (Ibis Biosciences, CA, USA) and phylogenetic analysis was performed using MEGA 5.1 (Tamura et al. 2011). The sequences (VP1 protein and RNA polymerase genes) were compared to a panel of reference sequences obtained from GenBank. Phylogenetic trees were generated using the neighbour-joining algorithm with bootstrap of 1,000 replicates and evolutionary distances were calculated using the Kimura two-parameter method.

Statistical analysis - Demographic and clinical data were compiled using JMP software v.5.2.1 and analysed using GraphPad Prism ${ }^{\circledR}$ v.5.03. Fisher exact or $\chi 2$ tests were used to assess differences between groups and the Mann Whitney test was used for continuous variables, as appropriate. Results for continuous data have been expressed as median \pm interquartile ranges. All $p$-values are two-tailed and a value of $<0.05$ was considered as significant.

TABLE II

Sequences of primers used for genome amplification and nucleotide sequencing of norovirus ${ }^{a}$

\begin{tabular}{|c|c|c|c|c|}
\hline Primer & Sequence 5'-3' & Product & Gene target & Genogroup \\
\hline Cap A & GGCWGTTCCCACAGGCTT & 177 bp & VP1 & GI \\
\hline Cap B1 & TATGTTGACCCTGATAC & & & \\
\hline Cap B2 & TATGTIGAYCCWGACAC & & & \\
\hline Cap C & ССТTYCCAKWTCCCAYGG & $253 \mathrm{bp}$ & VP1 & GII \\
\hline Cap D1 & TGTCTRSTCCCCCAGGAATG & & & \\
\hline Cap D3 & TGYCTYITICCHCARGAATGG & & & \\
\hline MJV12 & TAYCAYTATGATGCHGAYTA & $327 \mathrm{bp}$ & RNA & GI and GII \\
\hline Reg A & CTCRTCATCICCATARAAIGA & & polymerase & \\
\hline
\end{tabular}

$a$ : Vinjé et al. (2004). 


\section{RESULTS}

From 225 samples sent to the virology laboratory between September 2010-September 2011, 60 (26\%) were positive for at least one viral agent. HAdV was detected in $36(16 \%)$ samples, NoV in 19 samples $(8 \%)$ and RVA in 14 samples (6\%). Additionally, we observed five cases of mixed infection involving HAdV and RVA, three cases of HAdV combined with $\mathrm{NoV}$ and one case of triple infection involving RVA, HAdV and NoV. No cases of AstV infection were detected. Most positive samples were from patients older than two years. There were five case of RVA infection in a patient aged less than two years, who had not received the full vaccination or had underlying diseases with immunological impairment (Table III).

The mean number of stool samples sent to the laboratory was approximately 17 samples/month $( \pm 4.8)$, with an average of five positive samples/month $( \pm$ 2.6). The distribution of positive samples and its relation to the average monthly temperature $\left({ }^{\circ} \mathrm{C}\right)$ and precipitation $\left(\mathrm{cm}^{3}\right)$ between September 2010-September 2011 revealed the absence of a seasonal pattern for the studied viruses, as the pathogen detections occurred throughout the year (Fig. 1).

The group of patients that presented infection by one or more viral agents (infected group) was compared with the group of individuals who tested negative for any of the searched viral agents (not infected group). Significant differences were observed for the presence of fever $(p=0.0051)$ and the number of lymphocytes in the blood count $(\mathrm{p}=0.0224)$, which were higher in the infected group. Results were also obtained for faecal occult blood, parasites, reducing substances and stool culture, but the majority of the samples tested produced negative results, with no significant differences between the groups.

Nineteen samples were positive for $\mathrm{NoV}$ and from these we obtained 14 sequences for VP1 gene and 10 sequences for RNA polymerase gene to perform the phylogenetic analysis. These sequences were compared to VP1 genes, RNA polymerase genes and entire genome sequences of different NoV genotypes collected from GenBank. The final sequence alignment revealed 208 informative positions for analysis of VP1 gene and a phylogenetic tree was constructed (Fig. 2). Phylogenetic analysis of RNA polymerase gene was carried out, the results were the same as that performed with VP1 region (data not shown) and all sequences belonged to the genotype GII.4.

\section{DISCUSSION}

Analysis conducted previously in this hospital to assess the impact of vaccination against RVA indicated a reduction of $54.2 \%$ and $39.4 \%$ in medical consultations for children less than 12 months old and between 12-months, respectively, and a reduction of $44 \%$ in the number of hospitalisations for gastroenteritis in children less than 12 months. However, diarrhoea still represents a frequent cause of hospitalisation and, except for RVA, the role of other enteric viruses was not determined in our patients and their incidence was likely underestimated. Previously, we have carried out RV genotypic characterisation in all positive samples and G2 P[4] was the most prevalent genotype after the vaccine implementation in 2006 (Pereira et al. 2013).

Overall, $26 \%$ of samples were positive for enteric viruses, with $\mathrm{HAdV}$ the most frequent virus detected, corresponding to a frequency of $16 \%$. The prevalence of $\mathrm{HAdV}$ in prior studies has been variable, ranging from $0.7 \%$ to $>30 \%$ (Domínguez et al. 2009, Stroparo et al. 2010). In central Brazil, the state of Mato Grosso do Sul, AdVs were found in $3.6 \%$ of cases of AG (Andreasi et al. 2008), while other studies, such as those by Simpson et

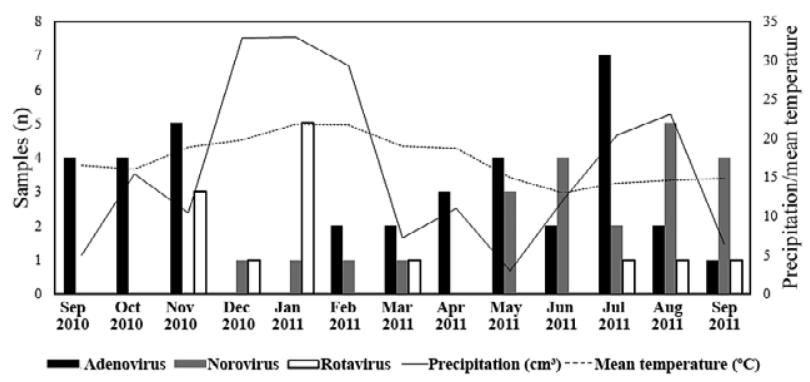

Fig. 1: distribution of positive samples for human adenovirus, norovirus, group A rotavirus and the correlation between rainfall and mean temperature from September 2010-September 2011. Source: Meteorological System of Paraná.

TABLE III

Enteric virus detected according to stratified age group

\begin{tabular}{lcccc}
\hline Virus & $\begin{array}{c}0-6 \text { months } \\
\text { (n) }\end{array}$ & $\begin{array}{c}7-12 \text { months } \\
\text { (n) }\end{array}$ & $\begin{array}{c}13-24 \text { months } \\
\text { (n) }\end{array}$ & $\begin{array}{c}>\text { months } \\
\text { (n) }\end{array}$ \\
\hline HAdV & 7 & 3 & 7 & 19 \\
NoV & 7 & 5 & 4 & 3 \\
RVA & 1 & 2 & 2 & 9 \\
AstVs & - & - & - & - \\
HAdV + RVA & - & - & 1 & 4 \\
HAdV + NoV & - & - & - & 2 \\
HAdV + RVA + NoV & - & - & - & 1 \\
\hline
\end{tabular}

AstVs: astrovirus; HAdV: human adenovirus; NoV: norovirus; RVA: group A rotavirus. 
al. (2003) and Cunliffe et al. (2010), have reported higher frequencies of HAdV ( $7.9 \%$ and $15 \%$, respectively). Previously, Pereira Filho et al. (2007) also reported a frequency of $2 \%$ of $\mathrm{AdV}$ antigen detection in hospitalised and community children with diarrhoea in Rio de Janeiro and Salvador, respectively. These lower frequencies might have been underestimated due to the technique used, that is, antigen detection. Subsequent introduction of molecular methods for studying this virus has led to a significant increase in the frequency of $\mathrm{AdV}$ detection in stools (Rohayem et al. 2004)

It is important to note that this study was carried out using a combination of generic primer for HAdVs detection, whose molecular sequencing of the products did not allow genotyping of detected virus. Then, the identified virus in the sample should not necessarily be considered the causative agent of the AG, as infections caused by some HAdV genotypes can result in an intermittent viral excretion in the stools after a previous infection. However, analysis of patient medical records did not reveal any further diseases that could be associated with other HAdV serotype infections. NoV was the second most common virus detected in the studied patients, responsible for $8 \%(19 / 225)$ of AG cases, with

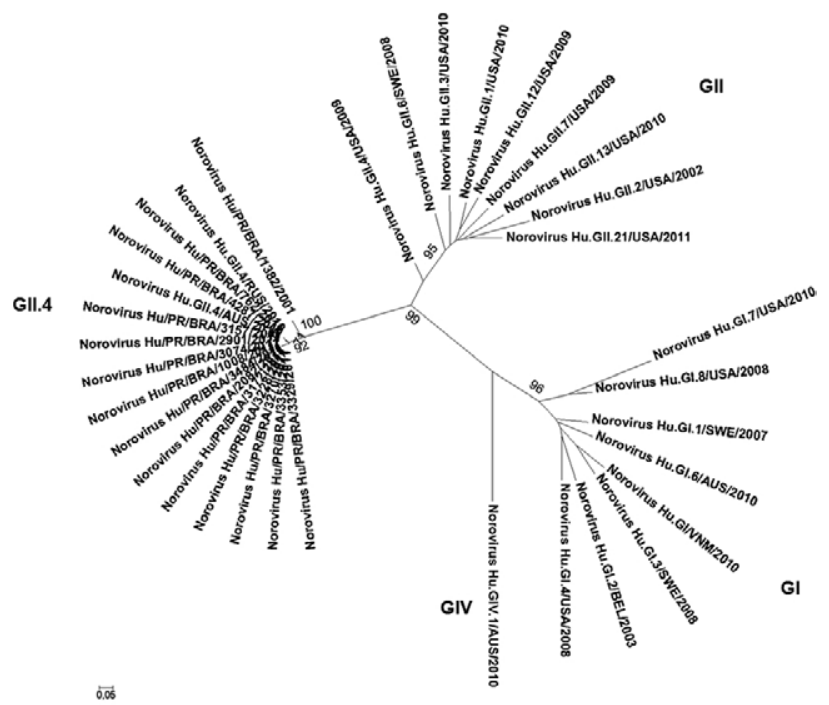

Fig. 2: neighbour-joining tree based on a 208 nucleotides sequence of the region of VP1, depicting phylogenetic relationships among norovirus from the state of Paraná, southern Brazil, and a reference panel of sequences obtained from GenBank. Sequences used as references in the analysis were as follows: JN797508.1, JQ320072.1, JN565063.1, JQ613565.1, HM596573.1, GU445325.2, JN183165.1, GU134965.1, HQ688986.1, JN899242.1, JN899245.1, JQ911594.1, FJ384783.1，FJ515294.1，JN603244.1，GQ413970.1，JQ388274.1, JN899243.1, GU299761.1 and JQ613567.1. GenBank accessions: PR BRA 1382 2001, KF556654, PR BRA 1008 2011, KF556655, PR_BRA_3074_2011, KF556656,PR_BRA_2082_2011, KF556657, PR_BRA_3172_2011, KF556658,PR_BRA_3228_2011, KF556659, PR BRA 3270 2011, KF556660, PR BRA 3329 2011, KF556661,PR_BRA_3353_2011, KF556662,PR_BRA_3484_2011, KF556663,PR_BRA_2901_2011, KF556664,PR_BRA_3157_2011, KF556665, PR_BRA_762_2011, KF556666, PR_BRA_4287_2010, KF556667. AUS: Australia; BEL: Belgium; BRA: Brazil; $\overline{\mathrm{Hu}}$ : human; PR: Paraná; RUS: Russia; SWE: Sweden; USA: United States of America; VNM: Vietnam.
RVA cases accounting for 6\% (14/225). Andreasi et al. (2008), in Brazil, reported similar findings, with NoV identified in $7.6 \%$ of the cases. Unlike the results of this study, Ferreira et al. (2012) in the states of Rio de Janeiro and Ribeiro et al. (2008) Espírito Santo identified this pathogen as the major viral agent in cases of gastrointestinal infections. Additionally, a study by Nakagomi et al. (2008) identified NoV in $15 \%$ of samples from the municipality of Recife, with clinical severity similar to that for RV, while in the municipality of São Paulo, Castilho et al. (2006) reported 33\% positive cases of NoV and Siqueira et al. (2013a) found $36.5 \%$ of positive samples in the municipality of Belém.

HAstV was not observed in this study. Some studies from other regions of Brazil and other countries (e.g., Japan, Greece and India) have also reported minimal circulation of this pathogen compared to other enteric viruses (Santos et al. 2007, Domínguez et al. 2009, Levidiotou et al. 2009, Chan-it et al. 2010, Verma et al. 2010). Usually, HAstV infections are not associated with severe AG, consequently, its identification in hospitalised patients might be uncommon. On contrary of our findings, a study carried out in Rio de Janeiro in 2004 shown a prevalence of $14 \%$ of AstV in the samples collected from hospitalised children with AG (Victoria et al. 2007). Interestingly, the protocol used in the present study was very similar to that reported, including the use of random primer to obtain cDNA and the sequences of specific primers employed in the PCR. Indeed, the prevalence of this virus in several studies is quite variable, epidemiological and seasonal factors should be considered in such analyses and studies that include laboratory surveillance for a longer time will be able to demonstrate the real impact of this pathogen on the children health.

$\mathrm{HAdV}$ and the NoV were detected during most of the months for which data were collected and although higher frequencies were observed in the fall and winter, no seasonal pattern or association with relative humidity was identified for these two viruses. Levidiotou et al. (2009) also failed to identify any seasonal pattern to the HAdV detected in Greece. However, Ozdemir et al. (2010) reported the presence of HAdV in the fall and winter months in Turkey, Kitajima et al. (2010) observed a higher frequency of NoV in winter and spring in Japan and Zeng et al. (2012) observed that the frequency of NoV peaks only during the cold months in China. Interestingly, similar to that reported by Siqueira et al. (2013b), we observed that the distribution of RVA and NoV positive cases throughout the year presented a distinct seasonal profile and a "seesaw effect".

Demographic data revealed no significant differences for age and gender between patients with or without viral infection. However, a trend was observed with infection occurring in younger children (median 30 months of age). Fever and vomiting were the most common symptoms presented and these were more frequent in the infected group than in the not infected group. Furthermore, significant lymphocytosis was observed in the infected group, although this parameter should be evaluated carefully since the quantity of lymphocytes in the blood can vary according to a child's age. Investigation of other pathogens associated 
to diarrhoea, as enteric bacteria and parasites, as well as other evidence of infection, such as the presence of faecal occult blood resulted as negative.

Phylogenetic analysis identified only genotype GII.4 at the study site, including the NoV detected in a sample collected in 2001. This result confirms the dominance of the genotype GII.4 circulation, already observed in other regions of Brazil, such as São Paulo, Vitória, Rio de Janeiro, Salvador and Belém, and other countries such as Venezuela, Mexico and Thailand (Castilho et al. 2006, Ferreira et al. 2008, Xavier et al. 2009, Aragão et al. 2010, Barreira et al. 2010, Khamrin et al. 2010, González et al. 2011, Gómez-Santiago et al. 2012).

Since 1995, NoV has caused five pandemics of AG and despite it has over 30 genotypes circulating, it is only a single genotype - GII.4 - that cause mass outbreaks and pandemics (Lindesmith et al. 2008). Factors intrinsic to the host and virus are associated with the higher prevalence of this genotype, among these are cited (i) GII.4 viruses bind to all blood group antigens and the ability to use blood groups antigens may affect the viral infectivity, differently of other genotypes (Tan \& Jiang 2005, Bull et al. 2010), (ii) the high capacity of the virus to alter its carbohydratebinding targets over time, allowing to escape from protective immunity (Lindesmith et al. 2008), (iii) the higher mutation rate and rate of evolution of GII.4 genotype compared to the less frequently detected NoV (GII.b, GII.3 and GII.7 strains) and (iv) GII.4 lineage had on average a 1.7-fold higher rate of evolution within the capsid sequence allowing the viral persistence (Bull et al. 2010).

Recently, Kroneman et al. (2013) proposed for a new NoV nomenclature: the identification of new genotypes should be based on the sequences of both genomic regions, open reading frame (ORF)1 and VP1. In the present study it was performed partial sequencing of both VP1 and ORF1 regions and in the phylogenetic analysis all viruses found were identified as GII.4, without any finding suggestive of recombinant forms between these samples.

Prior to implementation of the RVA vaccine, a reduction in the number of RVA positive samples in our hospital had already been observed, likely due to a number of factors including: improved sanitary conditions, greater access to basic healthcare and conversion of the institution from primary to tertiary care, where only patients with severe disease are referred. With the introduction of the vaccine, the reduction was even more impressive. However, the reduction in RVA circulation has been followed by an increased occurrence of HAdV and NoV and it is likely that we can expect an escalation in the frequency of occurrence of other enteric viruses, implying the need for more accurate laboratory investigation and improved epidemiological surveillance to guide prevention, therapeutic measures and control of outbreaks.

To our knowledge, this work represents the first report detailing the observed frequency of enteric viruses, other than RVs, which are associated with severe conditions responsible for hospitalisation of paediatric patients in southern Brazil. It is important to note the limitations of this study. First, genetic characterisation of the AdV detected should be performed to confirm the presence of the most frequent strains associated with AG, particularly genotypes 40 and 41 . Second, the investigation should be extended over a longer period to better assess the population distribution of these viruses and better evaluate seasonal patterns. Furthermore, prospective case-control studies, including the investigation AdVs in hospitalised children without diarrhoea should be implemented aiming to define the causal relation between the detection of these viruses and the presence of disease.

In conclusion, this study demonstrated that $26 \%$ of the AG identified in hospitalised children was associated with enteric viruses and that the introduction of RVA immunisation was associated with reduced frequency of this virus. However, reduction of RVA was followed by an increasing presence of other pathogens associated with severe clinical manifestations of AG in this population, highlighting the need to implement methods to routinely investigate these cases in a virology laboratory.

\section{REFERENCES}

Andreasi MS, Cardoso DD, Fernandes SM, Tozetti IA, Borges AM, Fiaccadori FS, Santos RA, Souza M 2008. Adenovirus, calicivirus and astrovirus detection in fecal samples of hospitalized children with acute gastroenteritis from Campo Grande, MS, Brazil. Mem Inst Osvaldo Cruz 103: 741-744.

Aragão GC, Oliveira DS, Santos MC, Mascarenhas JD, Oliveira CS, Linhares AC, Gabbay YB 2010. Caracterização molecular de norovírus, sapovírus e astrovírus em crianças com gastroenterite aguda em Belém, Pará, Brasil. Rev Pan-Amaz Saude 1: 149-158.

Avellón A, Pérez P, Aguilar JC, Lejarazu R, Echevarría JE 2001. Rapid and sensitive diagnosis of human adenovirus infections by a generic polymerase chain reaction. J Virol Methods 92: 113-120.

Bagci S, Eis-Hübinger AM, Yassin AF, Simon A, Bartmann P, Franz AR, Mueller A 2010. Clinical characteristics of viral intestinal infection in preterm and term neonates. Eur J Clin Microbiol Infect Dis 29: 1079-1084.

Barreira DM, Ferreira MS, Fumian TM, Checon R, de Sadovsky AD, Leite JP, Miagostovich MP, Spano LC 2010. Viral load and genotypes of noroviruses in symptomatic and asymptomatic children in southeastern Brazil. J Clin Virol 47: 60-64.

Black RE, Cousens S, Johnson HL, Lawn JE, Rudan I, Bassani DG, Jha P, Campbell H, Walker CF, Cibulskis R, Eisele T, Liu L, Mathers C, for the Child Health Epidemiology Reference Group of WHO, UNICEF 2010. Global, regional and national causes of child mortality in 2008: a systematic analysis. Lancet 375: 1969-1987.

Boschi-Pinto C, Velebit L, Shibuya K 2008. Estimating child mortality due to diarrhoea in developing countries. Bull World Health Organ 86: 710-717.

Bull RA, Eden JS, Rawlinson WD, White PA 2010. Rapid evolution of pandemic noroviruses of the GII.4 lineage. PLoS Pathog 6: e1000831.

Castilho JG, Munford V, Resque HR, Fagundes-Neto U, Vinjé J, Rácz ML 2006. Genetic diversity of norovirus among children with gastroenteritis in São Paulo state, Brazil. J Clin Microbiol 44: 3947-3953.

Chan-it W, Thongprachum A, Okitsu S, Mizuguchi M, Ushijima H 2010. Epidemiology and molecular characterization of sapovirus and astrovirus in Japan, 2008-2009. Jpn J Infect Dis 63: 302-303.

Chhabra P, Payne DC, Szilagyi PG, Edwards KM, Staat MA, Shirley SH, Wikswo M, Nix WA, Lu X, Parashar UD, Vinjé J 2013. Etiology of viral gastroenteritis in children $<5$ years of age in the United States, 2008-2009. J Infect Dis 208: 790-800. 
Cunliffe NA, Booth JA, Elliot C, Lowe SJ, Sopwith W, Kitchin N, Nakagomi O, Nakagomi T, Hart CA, Regan M 2010. Healthcareassociated viral gastroenteritis among children in a large pediatric hospital, United Kingdom. Emerg Infect Dis 16: 55-62.

Domínguez A, Godoy P, Torner N, Cardeñosa N, Martínez A 2009. Las gastroenteritis víricas: un problema de salud pública. Rev Esp Salud Publica 83: 679-687.

Ferreira MS, Xavier MP, Fumian TM, Victoria M, Oliveira SA, Pena LH, Leite JP, Miagostovich MP 2008. Acute gastroenteritis cases associated with noroviruses infection in the state of Rio de Janeiro. J Med Virol 80: 338-344.

Ferreira MS, Xavier MP, Tinga AC, Rose TL, Fumian TM, Fialho AM, de Assis RM, Costa FAC, de Oliveira SA, Leite JP, Miagostovich MP 2012. Assessment of gastroenteric viruses frequency in a children's day care center in Rio de Janeiro, Brazil: a fifteen year study (1994-2008). PLoS ONE 7: 1-7.

Gómez-Santiago F, Ribas-Aparicio RM, García-Lozano H 2012. Molecular characterization of human calicivirus associated with acute diarrheal disease in Mexican children. Virol J 9: 1-9.

González GG, Liprandi F, Ludert JE 2011. Molecular epidemiology of enteric viruses in children with sporadic gastroenteritis in Valencia, Venezuela. J Med Virol 83: 1972-1982.

Hardy ME 2005. Norovirus protein structure and function. FEMS Microbiol Lett 253: 1-8.

Justino MCA, Araújo EC, van Doorn L-J, Oliveira CS, Gabbay YB, Mascarenhas JDP, Miranda YS, Guerra SFS, da Silva VB, Linhares AC 2012. Oral live attenuated human rotavirus vaccine $\left(\right.$ Rotarix ${ }^{\mathrm{TM}}$ ) offers sustained high protection against severe G9P[8] rotavirus gastroenteritis during the first two years of life in Brazilian children. Mem Inst Oswaldo Cruz 107: 846-853.

Khamrin P, Maneekarn N, Thongprachum A, Chaimongkol N, Okitsu S, Ushijima H 2010. Emergence of new norovirus variants and genetic heterogeneity of noroviruses and sapoviruses in children admitted to hospital with diarrhea in Thailand. J Med Virol 82: 289-296.

Kitajima M, Oka T, Haramoto E, Takeda N, Katayama K, Katayama $\mathrm{H} 2010$. Seasonal distribution and genetic diversity of genogroups I, II and IV noroviruses in the Tamagawa River, Japan. Environ Sci Technol 44: 7116-7122.

Kroneman A, Vega E, Vennema H, Vinje J, White PA, Hansman G, Green K, Martella V, Katayama KK, Koopmans M 2013. Proposal for a unified norovirus nomenclature and genotyping. Arch Virol 158: 2059-2068.

Levidiotou S, Gartzonika C, Papaventsis D, Christaki C, Priavali E, Zotos N, Kapsali E, Vrioni G 2009. Viral agents of acute gastroenteritis in hospitalized children in Greece. Clin Microbiol Infect 15: 596-598.

Lindesmith LC, Donaldson EF, LoBue AD, Cannon JL, Zheng DP, Vinje J, Baric RS 2008. Mechanisms of GII.4 norovirus persistence in human populations. PLoS Med 5: e31.

Lopman BA, Payne DC, Tate JE, Patel MM, Cortese MM, Parashar UD 2012. Post-licensure experience with rotavirus vaccination in highand middle income countries: 2006 to 2011. Curr Opin Virol 2: 434-442.

Marshall JA, Bruggink LD, Sturge K, Subasinghe N, Tan A, Hogg GG 2007. Molecular features of astrovirus associated with a gastroenteritis outbreak in an aged-care centre. Eur J Clin Microbiol Infect Dis 26: 67-71.

McCollough M, Sharieff GQ 2006. Abdominal pain in children. Pediatr Clin N Am 53: 107-137.
Mead PS, Slutsker L, Dietz V, McCaig LF, Bresee JS, Shapiro C, Griffin PM, Tauxe RV 1999. Food-related illness and death in the United States. Emerg Infect Dis 5: 607-625.

Nakagomi T, Correia JB, Nakagomi O, Montenegro FM, Cuevas LE, Cunliffe NA, Hart CA 2008. Norovirus infection among children with acute gastroenteritis in Recife, Brazil: disease severity is comparable to rotavirus gastroenteritis. Arch Virol 153: 957-960.

Noel JS, Lee TW, Kurtz JB, Glass RI, Monroe SS 1995. Typing of human astroviruses from clinical isolates by enzyme immunoassay and nucleotide sequencing. J Clin Microbiol 33: 797-801.

Ozdemir S, Delialioğlu N, Emekdaş G 2010. Investigation of rotavirus, adenovirus and astrovirus frequencies in children with acute gastroenteritis and evaluation of epidemiological features. Mikrobiyol Bul 44: 571-578.

Patel MM, Hall AJ, Vinjé J, Parashar UD 2009. Noroviruses: a comprehensive review. J Clin Virol 44: 1-8.

Pereira Filho E, Faria NR, Fialho AM, Assis RS, Almeida MM, Rocha M, Galvão M, Santos FB, Barreto ML, Leite JPG 2007. Adenoviruses associated with acute gastroenteritis in hospitalized and community children up to 5 years old in Rio de Janeiro and Salvador, Brazil. J Med Microbiol 56: 313-319.

Pereira LA, Ferreira CE, Turchetto GD, Nogueira MB, Vidal LR, Cruz CR, Debur MC, Almeida SM, Raboni SM 2013. Molecular characterization of rotavirus genotypes in immunosuppressed and non-immunosuppressed pediatric patients. J Pediatr (Rio J) 89: 278-285.

Pereira LA, Raboni SM, Nogueira MB, Vidal LR, Almeida SM, Debur MC, Cruz C 2011. Rotavirus infection in a tertiary hospital: laboratory diagnosis and impact of immunization on pediatric hospitalization. Braz J Infect Dis 15: 215-219.

Pozo F, Tenorio A 1999. Detection and typing of lymphotropic herpesviruses by multiple polymerase chain reaction. J Virol Meth 79: 9-19.

Ramani S, Kang G 2009. Viruses causing childhood diarrhoea in the developing world. Curr Opin Infect Dis 22: 477-482.

Ribeiro LR, Giuberti RSO, Barreira DMPG, Saick KW, Leite JPG, Miagostovich MP, Spano LC 2008. Hospitalization due to norovirus and genotypes of rotavirus in pediatric patients, state of Espírito Santo. Mem Inst Oswaldo Cruz 103: 201-206.

RIPSA - Rede Interagencial de Informacão para a Saúde Brasil 2008. Indicadores básicos para a saúde no Brasil: conceitos e aplicações. Available from: tabnet.datasus.gov.br/tabdata/livroidb/2ed/indicadores.pdf.

Rohayem J, Berger S, Juretzek T, Herchenröder O, Mogel M, Poppe M, Henker J, Rethwilm A 2004. A simple and rapid single-stpe multiplex PCR to detect norovirus, astrovirus and adenovirus in clinical stool samples. J Virol Methods 118: 49-59.

Santos RA, Cardoso DD 2005. Astrovírus. Rev Patol Trop 34: 161-174.

Santos RAT, Borges AMT, da Costa PSS, Teixeira JMS, Giugliano LG, Leite JPG, Cardoso DDP 2007. Astrovirus infection in children living in the Central West Region of Brazil. Mem Inst Oswaldo Cruz 102: 209-213.

Simpson R, Aliyu S, Iturriza-Gómara M, Desselberger U, Gray J 2003. Infantile viral gastroenteritis: on the way to closing the diagnostic gap. J Med Virol 70: 258-262.

Siqueira JAM, Linhares AC, Carvalho TCN, Aragão GC, Oliveira DS, Santos MC, Sousa MS, Justino MCA, Mascarenhas JDP, Gabbay YB 2013a. Norovirus infection in children admitted to hospital for acute gastroenteritis in Belém, Pará, northern Brazil. J Med Virol 85: 737-744.

Siqueira JAM, Linhares AC, Gonçalves MS, de Carvalho TCN, Justino MCA, Mascarenhas JDP, Gabbay YB 2013b. Group A rota- 
virus and norovirus display sharply distinct seasonal profiles in Belém, northern Brazil. Mem Inst Oswaldo Cruz 108: 661-664.

Soares-Weiser K, MacLehose H, Bergman H, Ben-Aharon I, Nagpal S, Goldberg E, Pitan F, Cunliffe N 2012. Vaccines for preventing rotavirus diarrhoea: vaccines in use. Cochrane Database Syst Rev 12: CD008521.

Stroparo E, Cruz CR, Debur MC, Vidal LR, Nogueira MB, Almeida SM, Pereira LA, Rotta I, Raboni SM 2010. Adenovirus respiratory infection: significant increase in diagnosis using PCR comparing with antigen detection and culture methods. Rev Inst Med Trop Sao Paulo 52: 317-321.

Tamura K, Peterson D, Peterson N, Stecher G, Nei M, Kumar S 2011. MEGA5: molecular evolutionary genetics analysis using maximum likelihood, evolutionary distance and maximum parsimony methods. Mol Biol Evol 28: 2731-2739.

Tan M, Jiang X 2005. Norovirus and its histo-blood group antigen receptors: an answer to a historical puzzle. Trends Microbiol 13: 285-293.

Verma H, Chitambar SD, Gopalkrishna V 2010. Astrovirus associated acute gastroenteritis in western India: predominance of dual serotype strains. Infect Genet Evol 10: 575-579.

Victoria M, Carvalho-Costa FA, Heinemann MB, Leite JPG, Miagostovich MP 2007. Genotypes and molecular epidemiology of human astroviruses in hospitalized children with acute gastroenteritis in Rio de Janeiro, Brazil. J Med Virol 79: 939-944.
Vinjé J, Hamidjaja RA, Sobsey MD 2004. Development and application of a capsid VP1 (region D) based reverse transcriptionPCR assay for genotyping of genogroup I and II noroviruses. J Virol Methods 116: 109-117.

Vinjé J, Koopmans MP 1996. Molecular detection and epidemiology of small round-structured viruses in outbreaks of gastroenteritis in the Netherlands. $J$ Infect Dis 174: 610-615.

Walsh MP, Seto J, Jones MS, Chodosh J, Xu W, Seto D 2010. Computational analysis identifies human adenovirus type 55 as a re-emergent acute respiratory disease pathogen. $J$ Clin Microbiol 48: 991-993.

Wardlaw T, Salama P, Brocklehurst C, Chopra M, Mason E 2010. Diarrhoea: why children are still dying and what can be done. Lancet 375: 870-872.

Wold WS, Horwitz MS 2007. Adenoviruses. In DM Knipe, PM Howley, Fields virology, Lippincott Williams \& Wilkins, Philadelphia, p. 2395-2436.

Xavier MP, Oliveira SA, Ferreira MS, Victoria M, Miranda V, Silva MF, Strina A, Barreto ML, Miagostovich MP, Leite JP 2009. Detection of caliciviruses associated with acute infantile gastroenteritis in Salvador, an urban center in Northeast Brazil. Braz J Med Biol Res 42: 438-444.

Zeng M, Xu X, Zhu C, Chen J, Zhu Q, Lin S, Jie Y, Shu X 2012. Clinical and molecular epidemiology of norovirus infection in childhood diarrhea in China. J Med Virol 84: 145-151. 